\title{
Education of dietitian's in Brazil: Minimum clock hours of instruction for a bachelor's degree in nutrition
}

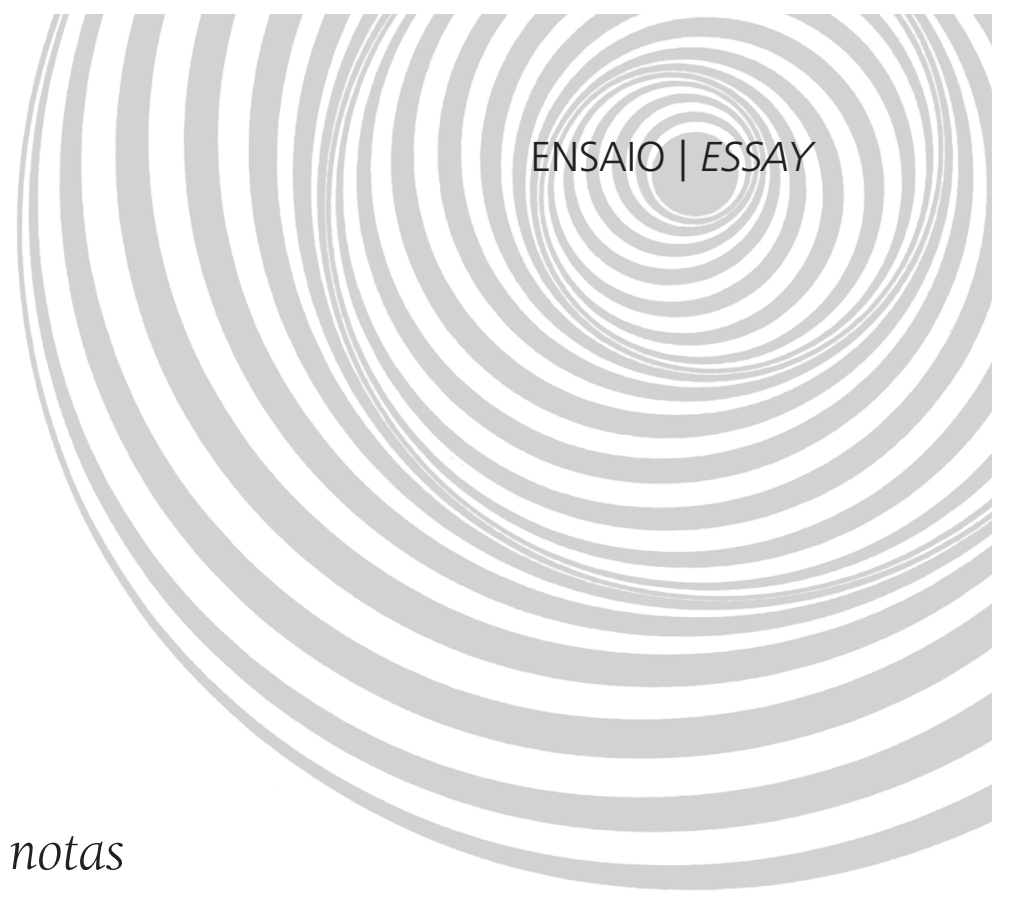

\author{
A formação de nutricionistas no Brasil: notas \\ para o debate sobre carga horária mínima \\ para integralização curricular dos \\ cursos de graduação
}

\author{
Maria Angélica Tavares de MEDEIROS' \\ Ligia AMPARO-SANTOS² \\ Semíramis Martins Álvares DOMENE ${ }^{1}$
}

\section{A B S T R A C T}

This essay aims to debate the minimum clock hours of instruction necessary for obtaining a bachelor's degree in nutrition considering the challenges to educate health professionals. Official documents on the minimum clock hours of instruction required by undergraduate nutrition programs were analyzed to investigate compliance with the curriculum guidelines for the area, the law that regulates the profession of dietitian, and the necessary education for the Sistema Único de Saúde (Unified Health Care System). Compared with other health programs, nutrition presented the smallest increase in the minimum clock hours of instruction required for the degree. The changes that occurred in the epidemiological, demographic, and nutritional profile of the population and scientific advances require specific nutrition actions. Since Sistema Único de Saúde focuses on comprehensiveness in the three levels of care, on humanization, and on health care, the theoretical and methodological concepts given in undergraduate programs need to be improved for the dietitians education to meet the Sistema Único de Saúde needs. Incorporation of the knowledge needed for working with food and nutritional phenomena, including its social and cultural dimensions, management of public policies, quantity cooking, and food and nutritional surveillance requires a higher minimum clock hours of instruction. In conclusion, dietitians need a minimum clock hours of instruction of 4,000 to acquire a proper education, integrate into the university life, and coordinate interdisciplinary experiences of the triad teaching/research/extension.

Indexing terms: Curriculum. Nutritionist. Health care. Health policy.

${ }^{1}$ Universidade Federal de São Paulo, Instituto Saúde e Sociedade, Departamento de Políticas Públicas e Saúde Coletiva. Edifício Central, R. Silva Jardim, 136, Vila Mathias, 11015-020, Santos, SP, Brasil. Correspondência para/Correspondence to: MAT

MEDEIROS.E-mail: <angelica.medeiros@unifesp.br>.

${ }^{2}$ Universidade Federal da Bahia, Escola de Nutrição, Departamento de Ciências da Nutrição. Salvador, BA, Brasil. 


\section{RE S U M O}

Este ensaio tem por objetivo discutir os atuais parâmetros de carga horária mínima para a integralização dos cursos de bacharelado em Nutrição, diante dos desafios para qualificar a formação profissional na área da saúde. Analisaram-se documentos oficiais sobre carga horária mínima de cursos de Nutrição para investigar o atendimento às diretrizes curriculares para a área, à lei que regulamenta a profissão de nutricionistas e às premissas de formação para o Sistema Único de Saúde. Verificou-se que, em comparação com outros cursos da saúde, o de Nutrição foi o que apresentou menor expansão de carga horária. As mudanças no perfil epidemiológico/demográfico/nutricional da população e os avanços do conhecimento requerem ações específicas de nutrição. A formação para o Sistema Único de Saúde, voltada à integralidade, nos três níveis de atenção à humanização e ao trabalho em saúde, exige aprimoramento das concepções teórico-conceituais e metodológicas para a graduação. A incorporação de saberes para atuar sobre fenômenos alimentares e nutricionais, incluindo a dimensão social/cultural, gestão de políticas públicas e da alimentação coletiva, além da vigilância alimentar e nutricional, demanda formação que ultrapassa a carga horária mínima em vigor. Em conclusão, sugere-se que o estabelecimento de 4 mil horas como carga horária mínima da graduação em Nutrição poderá contribuir para qualificar a formação e promover a integração do estudante na vida universitária, articulando vivências interdisciplinares no trinômio ensino/pesquisa/extensão.

Termos de indexação: Currículo. Nutricionista. Atenção à saúde. Política de saúde.

\section{NTRODUCTION}

The education of dietitians in Brazil has been the object of interest of many researchers especially because of the current epidemiological scenario which increasingly demands the specific work provided by this professional. The profession in Brazil has more than 70 years of history, a period marked by mobilizations led by professional entities and educational institutions to establish the profession, and discussions and reflections to define its profile, areas of competence, and curricular restructuring ${ }^{1-6}$.

The minimum Clock Hours of Instruction (CHI) for a bachelor's degree in nutrition was defined for the first time in 1962 by the Conselho Federal da Educação (National Education Council), who established a minimum $\mathrm{CHI}$ of 2,160 hours to be completed in three years. From then until the Diretrizes Curriculares (Curriculum Guidelines) of 2001, there was a long path of curriculum adjustments necessary to provide quality education in nutrition. At the end of the 1970s, the number of nutrition courses increased greatly in many Brazilian regions, boosted by the Reforma Universitária (University Reform) of 1968 and the Programa Nacional de Alimentação e Nutrição (II Pronan, National Food and Nutrition Program). Then, in 1974, the minimum curriculum for a bachelor's degree in nutrition was defined for the second time, with a minimum $\mathrm{CHI}$ of 2,880 hours to be completed in four years $2,5,7$.

More recently, in 2007, the Ministry of Education (MEC) established a minimum $\mathrm{CHI}$ of $3,200^{8}$. According to the Conselho Federal de Nutricionistas (CFN, Federal Council of Dietitians $)^{9,10}$, this $\mathrm{CHI}$ is not enough to provide an education that enables dietitians to face the demands of the complex Brazilian reality and the nutrition agenda in particular, with emphasis on the growing body of information on the role of foods in the treatment and prevention of various health problems ${ }^{11-13}$. This statement is further supported by the Curriculum Guidelines for a bachelor's degree in nutrition, which recommend increasing dietitians range of skills?

Studies done in the 2000s show the need to improve the undergraduate curriculum to provide dietitians with a generalist profile, 2,7,9. Other pieces of evidence from different areas of specialization point in the same direction, especially regarding public health ${ }^{14-16}$.

The objective of this essay was to debate the current minimum $\mathrm{CHI}$ for a bachelor's degree in nutrition (3,200 hours) established by the Conselho Nacional de Educação/Câmara de Educação Superior (CNE/CES, National Education 
Council/Higher Education Chamber) Report $n^{\circ} 213 / 2008^{17}$ in response to the need of preparing dietitians to face the contemporary health and nutrition scenario and to the revision that occurred in other health-related undergraduate programs.

\section{METHODS}

This essay is based on the documents that define the minimum $\mathrm{CH}$ for a bachelor's degree in nutrition, including official resolutions and reports. The documents covering other healthrelated undergraduate programs were also reviewed to compare how their minimum $\mathrm{CHI}$ changed over time with that of nutrition. The dietitians' competences and skills listed in the respective Curriculum Guidelines ${ }^{18}$ and in the Law $\mathrm{n}^{\circ} 8.234$, which regulates the profession ${ }^{19}$, are also discussed.

The $\mathrm{CHI}$ of nutrition programs throughout Brazil were obtained from the curricula of different programs provided by the Secretaria de Educação Superior (SESu-MEC, Higher Education Department), Instituto Nacional de Estudos e Pesquisas Educacionais (INEP, National Institute for Education Studies) and CFN. The literature was also searched for studies on the central theme of this essay.

The following documents were reviewed:

1) CNE/CES Report $n^{\circ} 329 / 2004$, which establishes the minimum $\mathrm{CHI}$ for in-person undergraduate nutrition programs ${ }^{20}$.

2) CNE/CES Report $n^{\circ} 8 / 2007$, which establishes the minimum $\mathrm{CHI}$, duration, and procedures for in-person undergraduate nutrition programs ${ }^{8}$.

3) CFN Report on the minimum $\mathrm{CHI}$ for undergraduate nutrition programs, established during the II professional education workshop?.

4) CNE/CES Report $n^{\circ}$ 213/2008, which establishes the minimum $\mathrm{CHI}$, duration, and procedures for the following in-person undergraduate programs: biomedicine, biological sciences, physical education, nursing, pharmacy, physiotherapy, speech-language pathologist, nutrition, or occupational therapy ${ }^{17}$.

5) CFN's Appeal to the CNE on November $19,2008^{10}$.

6) Resolution $n^{\circ}$ 4, issued on April 6, 2009 by $\mathrm{CNE} / \mathrm{CES}^{21}$.

7) MEC Ordinance $n^{\circ} 159 / 1965$, which ratifies the CFE 52/1965 Report and regulates the duration of undergraduate programs in Brazil22.

The documents listed above were thoroughly read and the data analyzed and treated. Descriptive analysis included the quantitative characterization of the $\mathrm{CHI}$ of nutrition programs throughout the country and the comparison between the minimum $\mathrm{CHI}$ for a bachelor's degree in nutrition over time and those for other health-related programs. The interpretative analysis was based on the recommendation of providing an education that focuses on multidisciplinary team work and comprehensive and humane care, as recommended by the Sistema Único de Saúde (SUS, Unified Health Care System) and the law that regulates the profession. This resulted in a debate about MEC's recommendation, focusing on the current challenges of the field of food and nutrition in Brazil.

Through document analysis, a relationship was established between the curriculum and the strategies necessary to give dietitians the skills and abilities needed in their work and the curricula adjusted to a minimum $\mathrm{CHI}$ of 3,200 . Hence, the theme was debated to contribute to a quality nutrition education.

This essay will first present a brief history of the changes in health education. Next, the changes that occurred in the minimum $\mathrm{CHI}$ for a bachelor's degree in nutrition over time will be discussed and compared with those of other health-related bachelor's degrees. Finally, the essay will approach the requirements and challenges of educating dietitians in today's world. 


\section{Changes in health education: A little about the history}

Traditionally, the core education of health professionals was based on the biological perspective, which has an individual character, and centered on the curative procedure, having the hospital as the entry point, and on the Flexnerian paradigm of medical assistance ${ }^{1,23}$. The result was an education that focused on teaching specialized techniques and procedures, often far from the health needs of the population.

In Brazil, the number of college graduates increased after the university reform that occurred at the end of the 1960s, creating departments and opening way to the privatization of higher education ${ }^{24}$. In the 1980s, the limitations of the education provided to health professionals began to be questioned, in a historical context of economic and social crisis resultant from the exclusionary facet of the capitalistic system established by the Military Government ${ }^{25}$. At the end of the 1970s and beginning of the 1980s, Brazil experienced intense mobilization of workers and sectors of the civil society ${ }^{26}$, and the health sector was marked by a movement for a health care reform which culminated with the creation of SUS in 1988 1,27,28.

Sistema Único de Saúde structuring demanded, in turn, the revision of the healthrelated undergraduate programs so that they could provide an education compromised with the principles and guidelines of this policy, which emphasized comprenhensive care, interdisciplinarity, team work, and the adoption of active teachinglearning methods. Hence, from the constitution of 1988 and SUS regulation in 1990, this movement forced the Ministry of Health to get more involved in the improvement of healthrelated higher education $23,27,29-32$.

In parallel, the technological revolution that occurred at the end of the $20^{\text {th }}$ century promoted changes in behavioral, physical activity, health, and nutrition patterns, requiring new perspectives from many social sectors ${ }^{25}$.
Professional profiles with strong knowledgefragmenting technical education induced the appearance of more comprehensive education proposals grounded on continuous improvement, global vision, and multidisciplinary team work. While debating the repercussions of globalization on society, Amâncio Filho ${ }^{27}$ warned that the health and education sectors need to be integrated to increase the range of skills provided by healthrelated education and to face the changes brought about by a globalized world.

To increase the scope of health-related higher education, the Curriculum Guidelines proposed by the Lei de Diretrizes e Bases da Educação (LDB of Education, Law of Education Guidelines and Foundations) of $1996^{33}$ and defined by CES/CNE in individual resolutions for each bachelor's degree include the incorporation of contents that address individuals and the historical and social understanding of the health and disease process. This inclusion generates a special model of care, as proposed by SUS, and represents a great advance towards quality health care, gaining international recognition. Therefore, the principles that support SUS are disclosed in the general instructions for the Curriculum Guidelines of health-related undergraduate programs and corroborated by a document that describes their trajectory?

In line with SUS, the Politica Nacional de Alimentação e Nutrição ${ }^{34}$ (PNAN, National Food and Nutrition Policy) established guidelines that promote the right to food security and the role of different social sectors for furthering healthy eating and preventing nutrition disorders. Instauration of the Associação Brasileira de Educação em Nutrição (ABENUT, Brazilian Association of Nutrition Education) in 2008 resulted from this movement and introduced the possibility of coordinating different actors, potentially strengthening education-related entities, such as councils, scientific associations, student organizations, and universities ${ }^{35}$.

It is in this scenario that the education of dietitians is being innovated. There are ongoing 
discussions about their professional profile and proposals of curricular reforms to increase their range of skills and prepare them for SUS' demands ${ }^{1,6}$. For this purpose, the definition of a minimum $\mathrm{CHI}$ gives the curriculum the opportunity to be more or less comprehensive.

\section{Account of the minimum $\mathrm{CHI}$ for a bachelor's degree in nutrition}

As mentioned earlier, the minimum $\mathrm{CHI}$ for the bachelor's degree in nutrition in Brazil was enacted twice, once in the 1960s and once in the 1970s, when the program was increased to four years with a minimum $\mathrm{CHI}$ of $2880^{1,2,5,7}$. Soares \& Aguiar (p.896) believe that the urgent need to change the core nutrition curriculum exists since the 1970s because "it did not keep up with the technical and scientific advances and does not meet the current needs of the Brazilian reality." With the creation of the Diretrizes Curriculares Nacionais de Graduação em Nutrição (DCN, National Curriculum Guidelines for Undergraduate Nutrition Programs) ${ }^{18}$ in 2001, it became easier to structure the curricula of undergraduate programs, allowing for greater autonomy and coherence with social demands.

According to the same document, higher education institutions were also given the prerogative to create programs that allowed graduates to fulfill the local and regional demands, which translates into dedicating part of the curriculum to disciplines that provide the skills and abilities that accomplish this purpose.

The Diretrizes Curriculares Nacionais became the official references for the definition of the minimum $\mathrm{CHI}$ for higher education programs, which, in the area of health care, was provided by CNE/CES Report $n^{\circ} 329 / 2004^{20}$, establishing a minimum $\mathrm{CHI}$ of 3,200 for the following undergraduate programs: Biomedicine, Physical Education, Nursing, Pharmacy, Physiotherapy, Speech-Language Pathology, nutrition, and occupational therapy. At the time, MEC suggested the revision of this document and welcomed many manifestations, such as that of the Forum dos Conselhos Profissionais (Forum of Professionals' Councils) which defended a minimum $\mathrm{CHI}$ of 4,000 for health-related undergraduate programs 9 .

In 2007, MEC issued the CNE/CES Report $\mathrm{n}^{\circ} 213^{8}$, where it established a minimum $\mathrm{CHI}$ of 4000 for the courses of physiotherapy, pharmacy, and nursing, and maintained a minimum $\mathrm{CHI}$ of 3,200 for the courses of nutrition, biomedicine, physical education, biological sciences, speechlanguage pathology, and occupational therapy ${ }^{1,9,35}$. According to CNE/CES Resolution $n^{\circ} 3$, issued on July 2, 200736, the total $\mathrm{CH}$ of these programs should be expressed as 60-minute classes of "effective student work and academic activities", regardless of hour/class duration, which can be defined by the higher education institution.

Comparison of the minimum $\mathrm{CHI}$ for nutrition and other programs shows that since the 1960s, the minimum CHI of most health carerelated programs increased to meet the demands of new pedagogical proposals. Figure 1 shows that the increase for some programs was smaller, such as nutrition, speech-language pathology, and occupational therapy, despite the increase in the number of these professionals in health care networks and other specific jobs.

A more thorough analysis was done by including other data provided by the CFN in 2009, such as type of management, number of seats, and total $\mathrm{CH}$ of undergraduate nutrition programs 9 . As a result, the mean $\mathrm{CHI}$ of Brazilian nutrition programs in 2009 was 3599, with a Standard Deviation (SD) of 386 hours/class (h/c).

With respect to type of management, the mean $\mathrm{CHI}$ for public universities (3,662, SD516h/ C) is higher than those for private institutions with a denominational, community, and/or philanthropic character (3646, SD369h/c) and other private institutions (3,555, SD344h/c). However, given the diversity of higher education institutions under the same type of management, these differences are not significant at the 95\% confidence level 
( $p=0.073)$. The number of seats offered by private institutions (151, SD101) was significantly higher $(p<0.001)$ than those offered by denominational, community, and/or philanthropic institutions $(112$, SD87), and public institutions (58, SD22).

Figure 2 shows the distribution of 327 undergraduate programs and their $\mathrm{CHI}$.

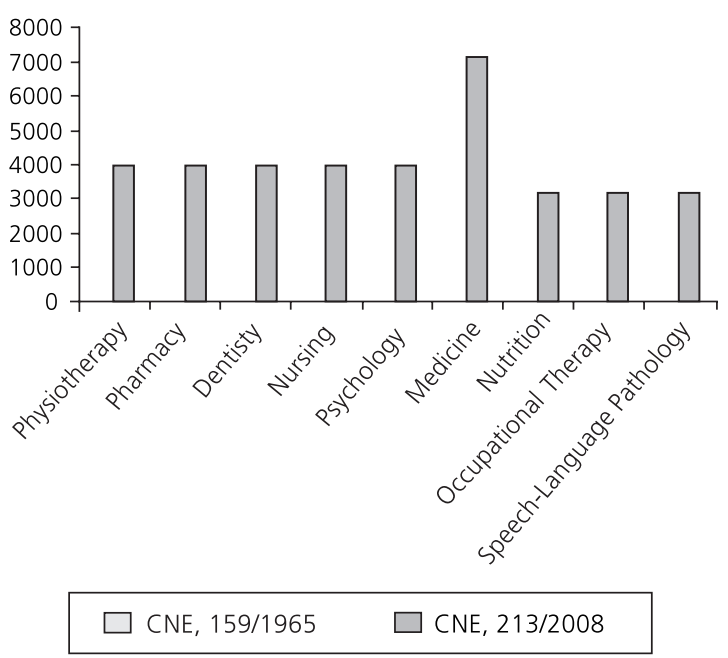

Figure 1. Changes in the minimum clock hours of instruction of health care-related undergraduate programs from 1965 to 2008. Brazil, 2009.

Source: Ministério da Educação, Ordinance 159/196522; Ministério da Educação, CNE Report 213/200817.

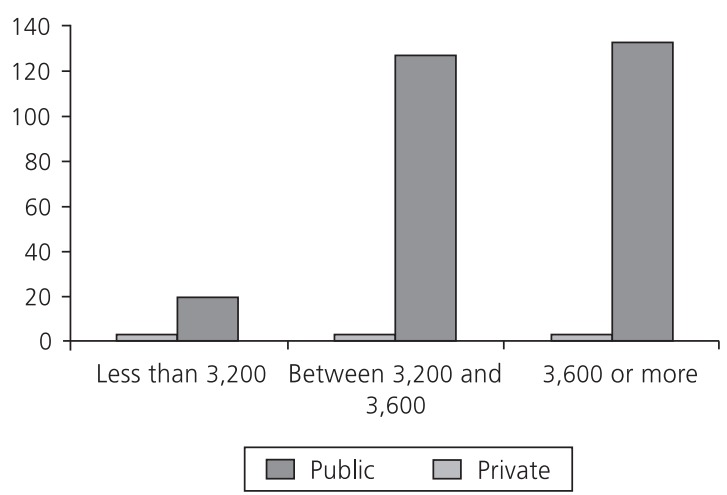

Figure 2. Distribution of undergraduate nutrition programs $(n=327)$ according type of management and clock hours of instruction. Brazil, 2009.

Source: Conselho Federal de Nutricionistas ${ }^{9}$.
Although limited by the absence of important elements, such as distribution by activities or subjects, the proportion between lecture, lecture-laboratory, and laboratory $\mathrm{CHI}$, and class duration, these data suggest that the mean $\mathrm{CHI}$ of nutrition programs in Brazil exceed the minimum $\mathrm{CHI}$ established recently for obtaining a bachelor's degree in nutrition, which configures a gap between the actual and the minimum recommended $\mathrm{CHI}$.

The scope of dietitians' education is revealed in the description of their profile, supplied by DCN Article $3^{18}$.

The dietitian has a generalist, humanist, and critical education and is capable of providing food safety and dietary care in all areas of knowledge in which food and nutrition are essential to promote, maintain, and recover health; and of preventing diseases in individuals or population groups, contributing to better quality of life, and based on ethical principles that reflect the economic, political, social, and cultural reality.

Compliance with other $D C N$ requirements indicates that there is a demand for programs that provide a type of teaching in which the "professor facilitates and mediates the teaching-learning process", and favors "complete and appropriate education by combining teaching, research, and extension/care" (Article 9).

By approaching the curriculum, the DCN promote strategies that train the student to "understand, interpret, preserve, reinforce, encourage, and diffuse international, national, regional, and historic cultures in a context of cultural pluralism and diversity". This purpose encourages the creation of curricula that include a wide range of subjects, such as social sciences, economy, anthropology, ethics, and deontology, not only in the first semesters but throughout the course.

Contrary to the belief that $\mathrm{CHI}$ does not impact education quality, the marked expansion 
of undergraduate nutrition programs in Brazil requires the establishment of the numbers that go with a curriculum. This establishment ensures that students acquire the skills and abilities stemming from new knowledge listed in the DCN and the demands of health care-related jobs. All this information begs the question: are 3,200 clock hours of instruction enough to provide the education dietitians need to meet the description of their profile?

\section{Demands and challenges for educating dietitians in today's world}

The wide range of competences and the CFN's definition of numerical parameters that enable nutritionists to be prepared for each one of those job possibilities require that undergraduate programs provide equally diversified learning opportunities $^{8}$. The need of preparing students for jobs in SUS which deal with patients in all three levels of care (primary, secondary, and tertiary) and the knowledge necessary to work in an interdisciplinary team require a proportion of the $\mathrm{CHI}$ to be dedicated to lecture-laboratory activities, exceeding 3,200 hours. When today's scenario resultant from the epidemiological and nutrition transition are compared with that of the 1970s, one sees that the nutritionist's work back then strongly focused on more biologically vulnerable groups, such as mothers and their newborns, since the epidemiological scenario at that time was very different from today's ${ }^{11}$.

Population-based studies show that the Brazilian dietary pattern has deteriorated in the last three decades, especially as staple foods are increasingly replaced by processed foods, making individuals more vulnerable to non-communicable health problems and diseases ${ }^{13,37}$. The coexistence of malnutrition and obesity in low-income population groups is another challenge to Brazilian public health managers, as is the need to regulate the intake of processed foods to preserve health ${ }^{13}$.
In the 2000s, new challenges emerged. The growing prevalence of non-communicable health disorders and diseases, the ageing population, and the original problems that were not yet resolved, such as endemic hunger, required a greater range of competences from dietitians. Therefore, following the trend observed for other health care-related professions, increasing the minimum $\mathrm{CHI}$ to 4,000 for undergraduate nutrition programs seems pertinent. The need to coordinate teaching, research, and extension have pressured the curriculum guidelines to encourage the restructuring of the pedagogical projects for undergraduate nutrition programs so that they can provide a learning experience that transcends strictly technical contents ${ }^{1,6,38}$. Thus, a minimum $\mathrm{CHI}$ of 3,200 prevents a comprehensive education.

With respect to the core curriculum, since the issuance of Law $n^{\circ} 8234$ in 1991, which regulates dietitians' work and establishes that only dietitians can prescribe diets, nutrition students had to learn more about physiopathology, genetics, immunology, nutritional recommendations, nutritional status indicators, and nutrition education, among others. In the area of clinical nutrition, the presence of dietitians in multidisciplinary nutritional therapy teams also required students to incorporate and master the technologies associated with nutritional support, so that they could perform better and have the power to decide the dietary prescription ${ }^{5,11}$.

The growing number of Equipes de Saúde da Familia (ESF, Family Health Teams) in Brazil reinforces this trend. In 2008, the ESF covered $49.3 \%$ of the Brazilian population, while the coverage of community health agents reached $60.1 \%{ }^{39}$. Dietitians have also been introduced in primary care, but the demand for dietitians has not yet been met ${ }^{14,15,30,40}$. The family health strategy and the creation of Núcleos de Apoio à Saúde da Familia (NASF, Family Health Support Units) in $2008^{41}$ reiterates the importance of this professional to guarantee a quality nutritional care that improves health. In March 2009, there were 457 NASFs in Brazil, of which 354 included dietitians ${ }^{42}$. 
Additionally, the urgent need to provide quality primary care service encouraged the Ministry of Health to propose the Pró-Saúde (Pro-Health), which has positive results for undergraduate nutrition programs: of the 265 undergraduate programs that participate in Pró-Saúde II, 35 are undergraduate nutrition programs, ranking third among the 14 health care-related undergraduate programs $\mathrm{s}^{42}$.

The higher life expectancy and consequent ageing of the population and the increasing complexity of scientific and technological apparatus require more skills and abilities and confirm the increasing number of jobs related to the nutritional care of the elderly, and the need to include gerontology, genomics, and pharmacology in the undergraduate curriculum ${ }^{5,11}$. The universalization of programs and guidelines launched by international agencies, such as the Global Strategy on Diet, Physical Activity and Health of the World Health Organization (WHO) further confirms the importance of nutrition for health-promoting actions, encouraging people to adopt healthy eating habits to prevent health problems ${ }^{16}$. Other factors, such as leadership roles in the management of public policies, the use of tools for food and nutrition surveillance, and the monitoring of the nutritional and health status of individuals and population groups, require mastering the subjects epidemiology, public health, statistics, planning, and management ${ }^{5,16}$.

The growth of the food service sector and the occupational health demands, especially regarding food and nutrition, are another area with the strong presence of dietitians who work simultaneously in management and dietary care ${ }^{5}$. The abovementioned growth is confirmed by the increasing prevalence of overweight and obesity and related comorbidities in workers ${ }^{43,44}$. Another aspect deserving of attention is work-and environment-related diseases, which would also benefit from dietitians' skillful care ${ }^{43,44}$. The Programa Nacional de Alimentação Escolar (PNAE, National School Food Program) also promoted a great demand for dietitians in the educational sector. In 2010, 45,6 million students from public and philanthropic kindergartens, elementary schools, middle schools, and high schools, and institutions that educate youth and adults benefited from the program, illustrating the importance of dietitians in public management ${ }^{2,3,45}$.

Learning new information that helps students to understand food and nutrition phenomena is also essential. Despite the role of biosciences in nutrition, the limitations of an approach based on nutrients are clear, not only because people consume foods and not nutrients, but also because of the challenges associated with food and nutrition issues of the $21^{\text {st }}$ century, such as the obesity epidemics. It is in this sense that the study of contemporary nutritional phenomena requires tools from the human and social sciences, including the cultural dimensions of eating and diet, the environmental issue, agricultural and food policies, and human rights issues in policies related to the universal access to healthy foods, among others ${ }^{5}$. Granted all the information disclosed herein, an increase in the minimum $\mathrm{CHI}$ of undergraduate nutrition programs will not necessarily improve the education provided to dietitians. Responding to the health and nutrition needs of the contemporary epidemiological scenario requires a reflection about the future nutritionist's job demands, and providing a comprehensive education helps to expose undergraduate students to different work areas.

Given the profound change in the Brazilian epidemiological profile, the scientific advances made in the area of nutrition and the growing trend to include dietitians in multidisciplinary teams, maintaining the current minimum $\mathrm{CHI}$ for undergraduate nutrition programs is not justified. In the last decades, the main areas of competence recognized by the CFN increased from three (clinical nutrition, quantity cooking, and social nutrition) to seven (the first three plus academia, sports nutrition, food industry, and food and nutrition marketing). The very specific characteristics, higher research output, and the increasing scope 
of competences of each area promoted the emergence of many subareas and an evergrowing specialization process $5^{7,40}$.

\section{CONCLUSION}

The limitations of the present essay do not allow us to conclude that the establishment of a minimum $\mathrm{CHI}$ of 4,000 for undergraduate nutrition programs is more appropriate. Besides, such establishment is not a merely technical decision, but also a political decision. Increasing the minimum $\mathrm{CHI}$ alone will not necessarily result in better education. Reconsidering this education requires more reflection about the professional profile of dietitians, their roles in the labor market, the curricula and teaching models that prevail in Brazilian higher education programs, and professor education, among others.

Despite these limitations, the considerations made herein suggest that the current minimum $\mathrm{CHI}$ of 3,200, the smallest among those of all health care-related undergraduate programs, is not enough to provide the education dietitians need. As mentioned earlier, it is not a matter of making the minimum $\mathrm{CHI}$ a prerequisite for quality education, much less of defending an increase in the minimum $\mathrm{CHI}$ only to increase the number of classes and/or disciplines. It seems clear that the inclusion of information critical for dietitians to perform well in their occupations requires a higher $\mathrm{CHI}$.

In conclusion, to meet the education demands of the $21^{\text {th }}$ century, a minimum $\mathrm{CHI}$ of 4,000 for undergraduate nutrition programs may improve dietitians' education, give higher education institutions more flexibility for their pedagogical projects, many of which already have much higher $\mathrm{CHI}$ than the required minimum, and reduce the discrepancies of the current $\mathrm{CHI}$ of undergraduate nutrition courses. A minimum $\mathrm{CHI}$ of 4,000 is similar to those of other health care-related undergraduate courses, whose areas of competence have also diversified and increased. Furthermore, curricula implemented in the last 13 years were carefully planned to give dietitians the generalist profile required by current social demands; their $\mathrm{CHI}$ are close to 4,000 .

\section{ACKNOWLEDGMENTS}

We thank the Secretaria de Gestão do Trabalho e da Educação na Saúde, Departamento de Gestão da Educação na Saúde (Department of Health-Related Labor and Education Management, Department of Health-Related Education Management) of the Ministry of Health for the support given to the development of the document that inspired this assay.

\section{CONTRIBUTORS}

T MEDEIROS, L AMPARO-SANTOS and SMA DOMENE designed the study, collected and analyzed data, searched the literature, wrote and reviewed the manuscript.

\section{REFERENCES}

1. Soares NT, Aguiar AC. Diretrizes curriculares nacionais para os cursos de nutrição: avanços, lacunas, ambiguidades e perspectivas. Rev Nutr. 2010; 23(5):895-905. doi: 10.1590/S1415-5273201000 0500019.

2. Vasconcelos FAG. O nutricionista no Brasil: uma análise histórica. Rev Nutr. 2002; 15(2):127-38. doi: 10.1590/S1415-52732002000200001.

3. Banduk MLS, Ruiz-Moreno L, Batista NA. A construção da identidade profissional na graduação do nutricionista. Interface. 2009; 13(28):111-20.

4. Costa NMSC. Formação pedagógica de professores de nutrição: uma omissão consentida? Rev Nutr. 2009; 22(1):97-104. doi: 10.1590/\$1415-5273200 9000100009

5. Vasconcelos FAG, Batista Filho M. História do campo da alimentação e nutrição em saúde coletiva no Brasil. Ciênc Saúde Colet. 2011; 16(1):81-90.

6. Santos LAS, Silva MCM, Santos JM, Assunção MP, Portel ML, Soares MD. Projeto pedagógico do programa de graduação em nutrição da Escola de Nutrição da Universidade Federal da Bahia: uma proposta em construção. Rev Nutr. 2005; 18(1):105-17. doi: 10.1590/S1415-52732005000100010. 
7. Simonard-Loureiro HM, Schwarzschild LFCP, Tuma RCFB, Domene SMÁ. Nutrição. In: Haddad AE, Pierantoni CR, Ristoff D, Xavier IM, Giolo J, Silva $L B$, editores. A trajetória dos cursos de graduação na área da saúde: 1991-2004. Brasília: INEP; 2006 [acesso 2011 ago 23]. Disponível em: <http:// bvsms.saude.gov.br/bvs/publicacoes/Texto_ de_Referencia.pdf>.

8. Brasil. Ministério da Educação. Parecer CNE/CES n 8/2007. Dispõe sobre carga horária mínima e procedimentos relativos à integralização e duração dos cursos de graduação, bacharelados, na modalidade presencial. Brasília: MEC; 2007 [acesso 2011 ago 23]. Disponível em: <http://portal.mec. gov.br/cne/arquivos/pdf/2007/pces008_07.pdf>.

9. Brasil. Conselho Federal de Nutricionistas. Carga horária mínima para graduação em Nutrição. Brasília: CFN; 2009 [acesso 2011 ago 18]. Disponível em: <http://www.cfn.org.br/novosite/ arquivos/PARECER-CFN-CARGA-HORARIAWORKSHOP-ENSINO.pdf>.

10. Brasil. Conselho Federal de Nutricionistas. Recurso ao Conselho Pleno do Conselho Nacional de Educação. Brasília: CFN; 2008 [acesso 2011 ago 18]. Disponível em: <http://www.cfn.org.br/novosite/ arquivos/Recurso_CNE.pdf>.

11. Vasconcelos FAG. A ciência da nutrição em trânsito: da nutrição e dietética à nutrigenômica. Rev Nutr. 2010; 23(6):935-45. doi: 10.1590/S1415-5273201 0000600001.

12. Schmidt MI, Duncan BB, Azevedo e Silva G, Menezes AM, Monteiro CA, Barreto SM, et al. Chronic non-communicable diseases in Brazil: Burden and current challenges. Lancet. 2011 [cited 2011 Jul 21]; 377(9781):1949-61. Available from: <http:// www.ncbi.nlm.nih.gov/pubmed/21561658>.

13. Monteiro CA, Levy RB, Claro RM, De Castro IRR, Cannon G. Increasing consumption of ultraprocessed foods and likely impact on human health: Evidence from Brazil. Public Health Nutr. 2011; 14(1):5-13.

14. Assis AMO, Santos SMC, Freitas MCS, Santos JM, Silva MCM. O Programa Saúde da Família: contribuições para uma reflexão sobre a inserção do nutricionista na equipe multidisciplinar. Rev Nutr. 2002; 15(3):255-66. doi: 10.1590/S1415-5273200200 0300001.

15. Pádua JG, Boog MCF. Avaliação da inserção do nutricionista na rede básica de saúde dos municípios da Região Metropolitana de Campinas. Rev Nutr. 2006; 19(4):413-24. doi: 10.1590/S141552732006000400001.

16. Recine $E$, Vasconcellos $A B$. Políticas nacionais e $O$ campo da alimentação e nutrição em saúde coletiva: cenário atual. Ciênc Saúde Colet. 2011; 16(1): 73-9.
17. Brasil. Ministério da Educação. Parecer CNE/CES nº 213/2008. Dispõe sobre a carga horária mínima e os procedimentos relativos à integralização e à duração dos cursos de graduação em Biomedicina, Ciências Biológicas, Educação Física, Enfermagem, Farmácia, Fisioterapia, Fonoaudiologia, Nutrição e Terapia Ocupacional bacharelados, na modalidade presencial. Brasília: MEC; 2008 [acesso 2011 ago 20]; Disponível em: <http://portal.mec.gov.br/cne/ arquivos/pdf/2008/ pces213_08.pdf>.

18. Brasil. Ministério da Educação. Resolução CNE/CES $\mathrm{n}^{\circ}$ 5, de 7 de Novembro de 2001. Institui diretrizes curriculares nacionais do curso de graduação em nutrição. Brasília: MEC; 2001 [acesso 2011 ago 18]. Disponível em: <http://portal.mec.gov.br/cne/ arquivos/pdf/CES05.pdf>.

19. Brasil. Lei $n^{\circ} 8.234$, de 17 de Setembro de 1.991 . Regulamenta a profissão de nutricionista e determina outras providências. Diário Oficial da União. 199118 set. [acesso 2011 jul 15]. Disponível em: <http://www.cfn.org.br/novosite/conteudo. aspx?IDMenu=56>

20. Brasil. Ministério da Educação. Parecer CNE/CES nº 329/2004. Dispõe sobre a carga horária mínima dos cursos de graduação, bacharelado, na modalidade presencial. Brasília: MEC; 2004 [acesso 2011 jun 15]. Disponível em: <http://portal.mec.gov.br/ cne/arquivos/pdf/2004/pces329_04.pdf>.

21. Brasil. Ministério da Educação. Resolução n 4, de 6 de abril de 2009. Dispõe sobre carga horária mínima e procedimentos relativos à integralização e duração dos cursos de graduação em Biomedicina, Ciências Biológicas, Educação Física, Enfermagem, Farmácia, Fisioterapia, Fonoaudiologia, Nutrição e Terapia Ocupacional bacharelados, na modalidade presencial. Brasília: MEC; 2009 [acesso 2011 ago 20]. Disponível em: <http://portal.mec. gov.br/dmdocuments/rces004_09.pdf>.

22. Brasil. Ministério da Educação. Portaria MEC 159/1965. Homologa o Parecer CFE 52/1965 e regulamenta a duração dos cursos de graduação no Brasil. Brasília: MEC; 1965.

23. Mitre SM, Siqueira-Batista R, Girardi-de-Mendonça JM, Morais-Pinto NM, Meirelles CAB, Pinto-Porto $C$, et al. Metodologias ativas de ensino-aprendizagem na formação profissional em saúde: debates atuais. Ciênc Saúde Colet. 2008; 13(Supl 2):2133-44.

24. Martins CB. A reforma universitária de 1968 e a abertura para o ensino superior privado no Brasil. Educ Soc. 2009; 30(106):15-35.

25. Chasin JA. Miséria brasileira: 1964-1994: do golpe militar à crise social. São Paulo: Estudos e Edições Ad Hominem; 2000.

26. Sader E. Quando novos personagens entraram em cena: experiências e lutas dos trabalhadores da 
grande São Paulo, 1970-1980. 2ª ed. São Paulo: Paz e Terra; 1988.

27. Amâncio Filho A. Dilemas e desafios da formação profissional em saúde. Interface. 2004; 8(15): 375-80.

28. Ceccim RB, Feuerwerker LCM. Mudança na graduação das profissões de saúde sob o eixo da integralidade. Ciênc Saúde Colet. 2004; 20(5): 1400-10.

29. Ceccim RB, Feuerwerker LCM. O quadrilátero da formação para a área da saúde: ensino, gestão, atenção e controle social. Physis. 2004; 14(1):41-65.

30. Medeiros MAT. Desafios do campo da alimentação e nutrição na atenção básica. In: Garcia RWD, Cervato-Mancuso AM, editores. Mudanças alimentares e educação nutricional. Rio de Janeiro: Guanabara Koogan; 2011. p.173-80.

31. Batista KBC, Gonçalves OSJ. Formação dos Profissionais de Saúde para o SUS: significado e cuidado. Saúde Soc. 2011; 20(4):884-99.

32. Feuerwerker LCM. Estratégias para a mudança na graduação das profissões da saúde. Cad ABEM. 2006 [acesso 2011 ago 25]; 2:78-80. Disponível em: <http://www.abem-educmed.org.br/publicacoes/ cadernos_abem/pdf_historia/mudanca_graduacao. $\mathrm{pdf}>$.

33. Brasil. Ministério da Educação. Lei n 9.394, de 20 de dezembro de 1996. Estabelece as diretrizes e bases da educação nacional. Brasília: MEC; 1996 [acesso 2011 ago 18]. Disponível em: <https:// www.planalto.gov.br/ccivil_03/Leis/L9394.htm>.

34. Brasil. Ministério da Saúde. Política nacional de alimentação e nutrição. $2^{a}$ ed. Brasília: MS; 2003 [acesso 2011 ago 18]. Disponível em: <http://189.2 8.128.100/nutricao/docs/geral/pnan.pdf>.

35. Veloso TCMA, Antunes MT, Peixoto OMC. A Associação Brasileira de Educação em Nutrição e sua inserção no Fnepas. Cad Fnepas. 2012 [acesso 2012 out 25]; 2:29-37. Disponível em: <http://www. fnepas.org.br/artigos_caderno/v2/associacao_ bras_educ.pdf>.

36. Brasil. Ministério da Educação. Resolução $n^{\circ} 3$, de 2 de Julho de 2007. Dispõe sobre procedimentos a serem adotados quanto ao conceito de hora-aula, e dá outras providências. Brasília: MEC; 2007 [acesso 2011 ago 20]. Disponível em: <http://www. educationet.com.br>.

37. Instituto Brasileiro de Geografia e Estatística. Pesquisa de orçamentos familiares 2008-2009: avaliação nutricional da disponibilidade domiciliar de alimentos no Brasil. Rio de Janeiro: IBGE; 2010.

38. Aguilar-da-Silva RH, Scapin LT, Batista NA. Avaliação da formação interprofissional no ensino superior em saúde: aspectos da colaboração e do trabalho em equipe. Avaliação. 2011; 16(1):165-84.

39. Brasil. Ministério da Saúde. Atenção básica e a saúde da família. Brasília: MEC; 2009 [acesso 2009 mar 17]. Disponível em: <http://dab.saude.gov.br/ abnumeros.php\#mapas>.

40. Brasil. Conselho Federal de Nutricionistas. Perfil da atuação profissional do nutricionista no Brasil. Brasília: CFN; 2006.

41. Brasil. Ministério da Saúde. Diretrizes do NASF: Núcleo de Apoio a Saúde da Família. Cadernos de Atenção Básica, 27. Brasília: MS; 2010 [acesso 2011 ago 23]. Disponível em: <http://189.28.128.100/ dab/docs/publicacoes/cadernos_ab/abcad27.pdf>.

42. Brito JA. Abrangência dos cursos de graduação em Nutrição do País no Programa Nacional de Reorientação da Formação em Saúde (Pró-Saúde). Brasília; 2009.

43. Medeiros MAT, Cordeiro R, Zangirolani LTO, Garcia RWD. Estado nutricional e práticas alimentares de trabalhadores acidentados. Rev Nutr. 2007; 20(6): 589-602. doi: 10.1590/S1415-527320070006000 02.

44. Canella DS, Bandoni DH, Jaime PC. Densidade energética de refeições oferecidas em empresas inscritas no programa de alimentação do trabalhador no município de São Paulo. Rev Nutr. 2011; 24(5): 715-24. doi: 10.1590/S1415-52732011000500005.

45. Brasil. Fundo Nacional de Desenvolvimento da Educação. Alimentação escolar: dados estatísticos. Brasília: FNDE; 2013 [acesso 2013 mar 27]. Disponível em: <http://www.fnde.gov.br/programas/ alimentacao-escolar/alimentacao-escolar-dadosestatisticos>.
Received on: 9/11/2012

Final version on: 2/4/2013

Approved on: 2/5/2013 
